\title{
Production of small and big fishes of selected ponds
}

\author{
Sabina Sultana \\ Department of Zoology, University of Rajshahi 6205, Bangladesh
}

\begin{abstract}
To study the big and Small Indigenous Species (SIS) of fish production, 15 ponds of Rajshahi University campus were selected. The pond production was ranged from 326.16 to $2187.40 \mathrm{~kg} / \mathrm{ha}$. The ratio of SIS and big fish production was calculated maximum as $1: 0.10$ (by number) and $1: 7.46$ (by weight). Majority of these SIS fish are Self Recruiting Species (SRS), because they were not stocked in the studied ponds. The F/C ratio was obtained as 4.583 in average.
\end{abstract}

Key Words: SIS, Production.

\section{Introduction}

Bangladesh is a country having vast water bodies with high production potential of fish which are very much nutritionally enriched. Fish is one of the most important sources of animal protein and has been widely accepted as a good source of protein and other elements for the maintenance of health body (Andrew, 2001) at low cost.

The Small Indigenous Species (SIS) of fish in Bangladesh are generally considered to be those which grow to a length of approximately $5-15 \mathrm{~cm}$ at maturity (Felts et al., 1996). Detailed biological information of these fishes are not presently available except few publications as stated by Hossain and Afroze (1991).

The SIS fishes have short life cycle and can grow in all types of inland waterbodies. Because of overfishing and reduced waterbodies a number of small fishes are now under the threat of extinction. In Bangladesh 143 freshwater fish species are categorized as small indigenous fish. In the past, these fishes were abundant in the rivers, beels, canals, streams and ponds. Both natural and man made catastrophes caused degradation of the aquatic environment, and reduction of many wet lands and water areas of Bangladesh have resulted in the disappearance of many suitable habitats for floodplain, riverine and brackish water small indigenous fish species. Many of these valuable small indigenous fish species have been threatened or endangered. Indeed, some are already on the verge of extinction. So, there is presently an urgent need to conserve and to increase the production of the SIS fishes through proper management of the waterbodies of Bangladesh. Side by side these species should be introduced in the farming systems of country.

Conservation of SIS can also help to control mosquito larvae. In the past, some of the small fishes were regarded as weed fishes and eradicated from the fish ponds using pesticides. But recently these species have been considered as an important source of essential macro and micro-nutrients, which can play an important role in the elimination of malnutrition in Bangladesh (Ahmed et al., 1997; Thilsted et al., 1997; Hossain, 1997; Hossain et al., 2003; Wahab et al., 2003 and Faculty of Fisheries, BAU, 2008).

The swamps are one of major source of small indigenous fish species in which it grow without care and without culture. These fishes enter in the swamps with the river water or flood water from the different sources, grow and reproduce there, so why is called as Self Recruiting Species (SRS).

The present research describes the production of SIS and big fishes from selected waterbodies. Where SIS fishes were not cultured they were naturally introduced.

\section{Materials and Methods}

\section{Study of the habitats}

Selected water bodies: For the present research, ponds of different types and swamps were selected. These waterbodies are situated within the Rajshahi University (RU) campus.

Total 15 ponds were selected.

\section{Fish production}

The total harvested weight of fishes of individual water bodies was recorded. Fishing of the swamps was done by cast net (larger fishes); and the smaller fishes were caught by hand after dewatering. Bamboo traps like Kholsoon and Dhiar were used to trap fish.

The ponds were harvested using encircled gill net and cast net. The miniponds were dewatered and fishing was done by hand. Total weight of individual species of bigger fishes were recorded.

However, fish diversity of the swamps was noted, with recording the total length $(\mathrm{cm})$ and total weight $(\mathrm{g})$ of the individuals of each species.

\section{Calculation of F/C ratio}

The ratio between the carnivorous and the other fishes (forage) (F/C ratio) were determined following Swingle's (1950) simple formula, as below:

$$
\mathrm{F} / \mathrm{C} \text { ratio }=\frac{\text { Weight of the forage fish }(\mathrm{F})}{\text { Weight of the carnivore fish }(\mathrm{C})}
$$

\section{Results and Observations}

\section{Description of the ponds}

Location: All the study ponds are situated scatteredly within the Rajshahi University campus. These ponds were formed gradually in man made dugout cavities made for different purposes

Pond type: Among the studied 15 ponds, in 10 water stand for 9 months, in five for 7 months. Other nine 
ponds are perennial. Pond no. 11 is not exactly a pond. It is a narrow natural canal.

Soil condition: The condition of the bottom soil of ponds are very important for fish culture. Among the 15 study ponds bottom of all ponds were sandy-muddy.

Water supply: The source of water of these ponds are rainwater, drain water, sewerage water. However, during the flood the flood water from rivers and canals also enter in these swamps.

Water area: The water area of these swamps ranged from $45.50 \mathrm{~m}^{3}$ to $1144 \mathrm{~m}^{3}$

Water colour: Water colour of most of the ponds was found to be greenish.

\section{Total production}

Total production by weight of SIS (C. fasciatus, $A$. testudineus, C. nama, C. ranga, $P$. ticto, $P$. gonionotus, C. reba, O. mossambicus, E. danricus, C. punctatus, $N$. nandas, A. mola, G. giuris, M. tengara, Prawn) and big (L. rohita, L. calbasu, C. cirrhosus, H. molitrix, C. carpio, A. nobilis, C. striatus, C. catla) fishes from individual pond are presented in Tables 1 and 2. Among the ponds, maximum production $135.863 \mathrm{~g} / \mathrm{m}^{3}$ was recorded from pond no. 10 , and minimum production was calculated as $16.31 \mathrm{~g} / \mathrm{m}^{3}$ in pond no. 13 (Table 2). The estimated weight produced per hectare of these ponds were ranged from $326.16 \mathrm{~kg} / \mathrm{ha}$ to $2187.40 \mathrm{~kg} / \mathrm{ha}$ in pond no. 13 and 10 respectively.
The ratio of production of SIS and big fishes in ponds were calculated as the minimum $1: 0.02$ in pond no. 6 (by number) and $1: 0.48$ in pond no. 14 (by weight); the maximum ratios are 1:0.13 (by number) in pond no. 11 and 1:7.46 (by weight) in the same pond, though the production rate of this pond (actually a canal) is too less compared to other ponds.

Ratio between carnivorous and forage fish (F/C
ratio) As production of the ponds which are not stocked or managed scientifically, and the fish population can be designated as "self recruiting species" (SRS), the ratio between the carnivorous and non-carnivorous (forage) fishes was determined to find out fish population these ponds (no. 1-15) are either balanced as unbalanced.

The F/C ratio of the fish population of individual 15 ponds are presented in Table 3 . The results show that the population of pond no. 2 and 14 are unbalanced having F/C ratio as $1: 2.79$ and 0.913 respectively (Table 3). The population of pond no. 2 was unbalanced due to higher production of forage fish than carnivore fish, and in other cases the production of carnivore fish was more than that of the forage fish. However, the total population of the ponds showed an average balanced value (Table 3).

Table-1. Pondwise production of SIS and big fishes by number and by weight in the studied ponds

\begin{tabular}{ccccccc}
\hline $\begin{array}{c}\text { Pond } \\
\text { No. }\end{array}$ & $\begin{array}{c}\text { Total no. of } \\
\text { small fishes }\end{array}$ & $\begin{array}{c}\text { Total weight } \\
\text { of small } \\
\text { fishes (g) }\end{array}$ & $\begin{array}{c}\text { Total no. } \\
\text { of big } \\
\text { fishes }\end{array}$ & $\begin{array}{c}\text { Total weight of } \\
\text { big fishes (g) }\end{array}$ & \multicolumn{2}{c}{ Ratio of SIS : big fish } \\
\cline { 6 - 7 } 1 & 463 & 4547.60 & 31 & 8974.00 & $1: 0.07$ & $1: 2.17$ \\
2 & 318 & 1234.40 & 16 & 7745.00 & $1: 0.05$ & $1: 6.27$ \\
3 & 524 & 3162.00 & 26 & 10380.00 & $1: 0.05$ & $1: 3.28$ \\
4 & 478 & 3646.00 & 26 & 11352.00 & $1: 0.05$ & $1: 3.11$ \\
5 & 496 & 2994.80 & 25 & 13697.00 & $1: 0.05$ & $1: 4.57$ \\
6 & 761 & 3071.30 & 12 & 6015.00 & $1: 0.02$ & $1: 2.22$ \\
7 & 566 & 3111.00 & 21 & 9500.00 & $1: 0.04$ & $1: 3.05$ \\
8 & 488 & 3827.00 & 28 & 11016.00 & $1: 0.06$ & $1: 2.88$ \\
9 & 565 & 4650.07 & 30 & 10892.00 & $1: 0.06$ & $1: 2.79$ \\
10 & 848 & 7391.00 & 33 & 11600.00 & $1: 0.04$ & $1: 1.57$ \\
11 & 62 & 636.00 & 8 & 4746.00 & $1: 0.13$ & $1: 7.46$ \\
12 & 868 & 8489.00 & 78 & 49382.00 & $1: 0.09$ & $1: 5.82$ \\
13 & 324 & 3244.20 & 32 & 5660.00 & $1: 0.10$ & $1: 1.74$ \\
14 & 265 & 1116.11 & 15 & 535.00 & $1: 0.06$ & $1: 0.48$ \\
15 & 158 & 1664.60 & 16 & 1185.00 & $1: 0.10$ & $1: 0.71$ \\
\hline
\end{tabular}


Table-2 The average fish production per unit area of different ponds

\begin{tabular}{ccccccc}
\hline \multirow{2}{*}{$\begin{array}{c}\text { Pond } \\
\text { No. }\end{array}$} & \multicolumn{3}{c}{ Area } & \multicolumn{4}{c}{ Production } \\
\cline { 2 - 7 } & Area $\left.\mathbf{( m}^{2}\right)$ & Water area & Total wt. of & Weight/m & Weight/m $\mathbf{~} \mathbf{( g )}$ & Weight per \\
\hline 1 & 82.22 & 124.97 & 13521.60 & 164.4563 & 108.1988 & 1644.56 \\
2 & 82.03 & 124.69 & 8979.40 & 109.4648 & 72.0138 & 1094.65 \\
3 & 86.64 & 139.48 & 13542.00 & 156.3019 & 97.0892 & 1563.02 \\
4 & 87.42 & 131.13 & 14998.00 & 171.5626 & 114.3750 & 1715.63 \\
5 & 89.30 & 133.95 & 16691.80 & 186.9183 & 124.6122 & 1869.18 \\
6 & 85.32 & 128.83 & 9086.30 & 106.4967 & 70.5294 & 1064.97 \\
7 & 86.82 & 140.65 & 12611.00 & 145.2545 & 89.6623 & 1452.55 \\
8 & 81.78 & 122.67 & 14843.00 & 181.4991 & 120.9994 & 1814.99 \\
9 & 88.35 & 132.53 & 15542.70 & 175.9219 & 117.2768 & 1759.22 \\
10 & 86.82 & 139.78 & 18991.00 & 218.7399 & 135.8635 & 2187.40 \\
11 & 74.989 & 44.99 & 5382.00 & 71.7705 & 119.6266 & 717.71 \\
12 & 880.00 & 1144.00 & 57871.00 & 65.7625 & 50.5865 & 657.63 \\
13 & 273.00 & 546.00 & 8904.20 & 32.6161 & 16.3081 & 326.16 \\
14 & 50.00 & 45.50 & 1651.11 & 33.0222 & 36.2881 & 330.22 \\
15 & 572.00 & 572.00 & 2849.60 & 4.9818 & 4.9818 & 49.82 \\
\hline
\end{tabular}

Table-3 . Forage fish and carnivorous fish production in ponds and F/C ratio

\begin{tabular}{|c|c|c|c|c|c|c|c|}
\hline \multirow{2}{*}{ SI. No. } & \multicolumn{2}{|c|}{ Forage fish } & \multicolumn{2}{|c|}{ Carnivorous fish } & \multirow{2}{*}{$\begin{array}{l}\text { Value of } \\
\text { F/C ratio }\end{array}$} & \multirow{2}{*}{$\begin{array}{l}\text { Balanced (B) or } \\
\text { Unbalanced (U) } \\
\text { production }\end{array}$} & \multirow{2}{*}{$\begin{array}{l}\text { Average } F / C \text { ratio } \\
\text { in ponds }(n=15)\end{array}$} \\
\hline & No. & $W t(g)$ & No. & Wt (g) & & & \\
\hline 1 & 179 & 9952.8 & 351 & 3568.8 & 2.788 & B & \multirow{15}{*}{$\begin{array}{c}4.583 \\
\text { (Balanced) }\end{array}$} \\
\hline 2 & 141 & 8221 & 193 & 758.4 & 10.897 & $U$ & \\
\hline 3 & 206 & 10880 & 344 & 2662 & 4.087 & B & \\
\hline 4 & 236 & 12120 & 268 & 2878 & 4.211 & B & \\
\hline 5 & 226 & 14520 & 295 & 2171.8 & 6.685 & B & \\
\hline 6 & 442 & 7220 & 331 & 1866.3 & 3.868 & B & \\
\hline 7 & 205 & 10192 & 382 & 2419 & 4.213 & B & \\
\hline 8 & 293 & 12388 & 223 & 2455 & 5.046 & B & \\
\hline 9 & 272 & 12394 & 323 & 3148.7 & 3.936 & B & \\
\hline 10 & 457 & 13574 & 424 & 5417 & 2.505 & B & \\
\hline 11 & 45 & 4882 & 25 & 500 & 9.764 & B & \\
\hline 12 & 441 & 50240 & 505 & 7631 & 6.583 & B & \\
\hline 13 & 162 & 6115 & 194 & 2789.2 & 2.192 & B & \\
\hline 14 & 89 & 788.11 & 191 & 863 & 0.913 & $U$ & \\
\hline 15 & 96 & 1469 & 78 & 1380.6 & 1.064 & B & \\
\hline
\end{tabular}

\section{Discussion}

The present results showed that as a habit the small waterbodies with rich aquatic vegetation and permitted to be flooded, can yield or produce a satisfactory quantity (by number and by weight) of a variety of both indigenous and introduced a number of SIS fishes which were naturally introduced, are listed as highly nutritious and containing vitamins and minerals (Roos et al., 2003). Among the SIS fishes, mola fish (is also a SRS) have been successfully introduced in the commercial fish farms in carp polyculture system (Roos et al., 2003). Alam (2009) suggested that the featherback $N$. notopterus can be cultured with carps without affecting the production. 
Swingle (1950) suggested that in the balanced population the $\mathrm{F} / \mathrm{C}$ ratio will range from 1.4 to 10 . Among the 15 experimental ponds, 13 showed balanced population. The average F/C ratio of the ponds was determined as 4.583 which is a balanced population. The unbalanced population is that one which unable to produce accepted amount of fish year after year (Swingle, 1950). When the carnivorous fish is dominant in the water body the F/C ratio is unbalanced, and as a result the fish production is less. So, the entry of the carnivorous fishes in any fish culture area is likely to affect the fish production (Hasan, 1983).

In Bangladesh total annual fish production from pond and ditch was $2839 \mathrm{~kg} / \mathrm{ha}$ from July 2007-June 2008 (DoF, 2007-2008). The fish production in our country is comparatively less than other countries. Jhingran (1977) noted the all time Indian record fish production was 9,056 $\mathrm{kg} / \mathrm{ha} / \mathrm{yr}$. A maximum fish production from freshwater ponds of China was reported as 7.5 tons/ha/yr (Lin, 1982). Lakshmanan et al. (1971) reported the average production to be $3,062 \mathrm{~kg} / \mathrm{ha} / \mathrm{yr}$, while Sinha et al. (1973) found $3232.30 \mathrm{~kg} / \mathrm{ha}$ production in six months. Davis et al. (1983) recorded fish yields ranging from 1980 to 3,820 $\mathrm{kg} / \mathrm{ha} / \mathrm{yr}$. Miah et al. (1993) obtained a gross production of $3,670 \mathrm{~kg} / \mathrm{ha}$ from polyculture of Indian major carps and Chinese carp. Uddin et al. (1994) obtained a production of 2,019 to $3,415.60 \mathrm{~kg} / \mathrm{ha} / \mathrm{yr}$ and Mazid et al. (1997) found a gross production ranging from 2545.50 to $3687.80 \mathrm{~kg} / \mathrm{ha} / 11$ month from carp polyculture system.

Production of SIS fishes both in diversity and biomass, were found comparatively higher in small unmanaged ponds than in large stocked fish ponds. Total production of ponds in 9 months period was obtained maximum as $2187.40 \mathrm{~kg} / \mathrm{ha}$ Total SIS production for ponds was ranged from 0.636 to $7.391 \mathrm{~kg}$. Most of the ponds were found to be a balanced one, from their $\mathrm{F} / \mathrm{C}$ ratio of fish biomass.

\section{References}

Ahmed K, Hossain MA, Huda N \& Abdullah M. 1997. Nutritional survey of rural Bangladesh; 1975-76. Institute of Nutrition and Food Science, University of Dhaka, $66 \mathrm{pp}$

Alam MM. 2009. Bionomics of Notopterus notopterus (Pallas, 1769). Ph.D. Thesis, Department of Fisheries, Rajshahi University, 195pp.

Andrew AE. 2001. Fish Processing Technology. University of Ilorin Press, Nigeria, pp. 7-8.

Davis $\mathrm{CH}$, Bhuiyan AR \& Ameen M. 1983. Fish production in managed farmers pond with different feeding and stocking regimes-Raipur, Noakhali district. ADAB News, Dhaka. 10(2): 2-26.

DoF. 2008. Annual Report of activities by Fisheries Office 2007-2008, and Future Planning, 2008, Rajshahi Division (in Bangla Department of Fisheries, Rajshahi Division 40pp.

Faculty of Fisheries, BAU, 2008. Book of AbstractsRegional Workshop on Production and Conservation of Small Indigenous Fish Species (SIS) for Improved Food \& Nutrition Security and Livelihoods of Rural Populations of South \& Southeast Asia. Faculty of Fisheries, Bangladesh Agricultural University, Mymensingh, Bangladesh. 36p.
Felts RA, Rajts F \& Akhteruzzaman M. 1996. Small Indigenous fish species culture in Bangladesh. IFADEP Sub-Project-2. Development of Inland Fisheries, 41pp.

Hasan AFM. 1983. Boyiganic Upaya Matsho Chas (In Bengali). Krishikatha, $5^{\text {th }}$ ed. Aug-Sept. Krishikatha Saang, Dhaka 3.10 .

Hossain MA \& Afroze S. 1991. Small Fisheries as Resource in Rural Bangladesh. Fishbyte. 9(2):15-18.

Hossain MA. 1997. Various aspects of small indigenous species (SIS) of fish in Bangladesh. Proc. Nat. Workshop on SIS Culture in Bangladesh. December 12, 1996, Key note speech, IFADEP September 2, 16-30.

Hossain MA, Ahsan MK \& Hussain MA. 2003. Small fish resources in the rivers, flood plains and upland areas of Bangladesh. Proceeding of BAU-ENRECA/DANIDA Workshop on Potentials of Small Indigenous Species of Fish (SIS) in Aquaculture \& Rice-Field stocking for Improved Food \& Nutrition Security in Bangladesh, 30-01 October, 2002, BAU, Mymensingh, Bangladesh, pp. 87-96.

Jhingran VG. 1977. Fish and Fisheries of India, $2^{\text {nd }}$ edn. Hindusthan Publ. Corp. India, 954pp.

Lakshmanan MAV, Sukumaran KK, Murty DS, Chakraborty DP and Philipose MT. 1971. Preliminary observations on intensive fish farming in freshwater ponds by the composite culture of Indian and exotic species. J. Inland Fish. Soc. India. 3: 2-21.

Lin HR. 1982. Polyculture systems of freshwater fish in China. Can. J. Fish. Aqua. Sci. 39: 143-150.

Mazid MA, Zaher M, Begum NN, Ali MA \& Nahar F. 1997. Formulation of cost effect feeds from locally available ingredients for carp polyculture systems for increased production. Aquaculture, 151: 71-78.

Miah MS, Uddin MS \& Shah MS. 1993. Effects of supplementary feed in carp polyculture systems. Bangladesh J. Agril. Sci. 29(2): 359-364.

Roos N, Islam MM and Thilsted SH. 2003. Animal source foods to improve micronutrient nutrition and human function in developing countries. J. Nutr. 133: 4021S-4026S.

Sinha VRP, Gupta MV, Banerjee MR \& Kumar. 1973. Composite fish culture Kalyani. West Bengal. J. Inland Fish. Soc. India. 5: 201-207.

Swingle HS. 1950. Fish Pond Population. Fishery Science. John Willey and Sons. Inc. New York, London, Sydney, 1966, 129-135.

Thilsted SH, Roos N \& Hossain N. 1997. The role of small indigenous fish species in food and nutrition security in Bangladesh. NAGA. The ICLARM Quarterly, July-December: 13-15.

Uddin MS, Miah MS \& Alam MS. 1994. Study on production optimization through polyculture of indigenous and exotic carps. Bangladesh $\mathrm{J}$. Train. and Dev. 7(2): 67-72.

Wahab MA, Thilsted SH \& Hoq ME (eds). 2003. Small indigenous species of fish in Bangladesh. Proceedings of BAUENRECA/DANIDA Workshop on Potentials of small indigenous species of fish (SIS) in aquaculture and rice-field stocking for improved food and nutrition security in Bangladesh, 30-31 October 2002, Bangladesh Agricultural University, Mymensingh, Bangladesh and ENRECA / DANIDA. 166p. 